\title{
Disk chain effects on seeded grass establishment
}

\author{
H. T. WIEDEMANN AND B. T. CROSS
}

Authors are Professor of Agricultural Engineering and Research Associate, Texas Agricultural Experiment Station, P.O. Box 1658, Vernon, Tex. 76385.

\begin{abstract}
Preparing a seedbed and seeding rangeland littered with brush debris normally requires extensive land cleanup before conventional equipment can be used. Our 3-year study compared grass densities on seedbeds prepared with an anchor chain, a diskchain implement, and the disk chain followed by an anchor chain on land rootplowed for mesquite (Prosopis glandulosa Torr. var. glandulosa) control. Seedbeds were aerially seeded with 1 or 2 kg/ha pure live seed of kleingrass (Panicum coloratum L.). Treatments were applied to a clay loam and sandy loam site each year. Evaluations were based on established grass densities at the end of the first growing season. A heavy-duty, offset disk was included in the seedbed preparation methods during the third year. The chain, disk-chain, and disk-chain+chain implements traversed the log-littered sites without difficulty. Seedbeds prepared by disk-chaining+chaining significantly $(\mathbf{P}<0.05)$ increased plant densities by $100 \%$ in clay loam soil and $42 \%$ in sandy loam soil compared with seedbeds prepared by chaining. However, in the year when rainfall was $43 \%$ below normal at the clay loam site, disk-chaining+chaining increased plant densities by $218 \%$ compared with chaining. Plant densities on disk-chained seedbeds were lower than those on disk-chained+chained seedbeds in clay loam soil while densities on disk-chained seedbeds were significantly $(P<0.05)$ lower than densities on diskchained+chained seedbeds in the sandy loam soil, but densities following disk chaining were significantly $(P<0.05)$ higher than densities following chaining in both soil types. There was no difference in plant densities between disked and diskchained+chained seedbeds; consequently, there would be little need to rake up the brush so a disk could be used. The $2 \mathrm{~kg} / \mathrm{ha}$ seeding rate compared with the $1 \mathrm{~kg} / \mathrm{ha}$ seeding rate significantly $(P<0.05)$ increased plant densities by $75 \%$ in the clay loam and $98 \%$ in the sandy loam soil. The results from this study indicate the value of using the disk-chain+chain implement, and the higher seeding rate to enhance the establishment of a seeded grass, especially when rainfall is in short supply or not timely.
\end{abstract}

Key Words: seedbed, rangeland seeding, brush control, mesquite, Prosopis glandulosa

Mention of a trade name is for identification only and does not imply an endorsement or preference over other products not mentioned.

The authors are grateful for the cooperation and funding provided by the E. Paul and Helen Buck Waggoner Foundation and the W.T. Waggoner Estate, Vernon,Tex.; Pitchfork Land and Cattle Co., Guthrie, Tex.; Brush Control and Range Improvement Association, Albany, Tex.; Hardcastle Ag-Air, Vernon, Tex; and Post Contractors, Post, Tex. We want to thank Omer Jenkins, Dept. of Statistics, Texas A\&M Univ., College Station, Tex., for his assistance with statistical analyses, Gerral Schulz, Texas Agr. Exp. Sta., Vernon, Tex., who fabricated the equipment, and the Texas Agr. Ext. Ser. and NRCS, Vernon, Tex., for their assistance with site locations and soils maps.

Manuscript accepted 28 March 1999

\section{Resumen}

Preparar una cama de siembra y sembrar un pastizal con muchos residuos de arbustos normalmente requiere de mucha labor de limpieza antes de que un equipo convencional pueda ser utilizado. En nuestro estudio de tres años comparamos 3 densidades de zacates en camas de siembra preparadas con una cadena de ancla, un implemento de cadena de discos y el implemento de cadena de discos seguido por la cadena de ancla en un terreno preparado con arado de subsuelo para el control de mezquite (Prosopis glandulosa Torr. Var. glandulosa). Las camas de siembra se sembraron vía aérea con una densidad de 1 o $2 \mathrm{~kg}$ de semilla pura viable de "Kleingrass" (Panicum cloratum L.). Los tratamientos se aplicaron cada año en un sitio franco - arcilloso y otro franco- arenoso. Las evaluaciones fueron realizadas al final de la primera estación de crecimiento en las densidades de zacates establecidos. En el tercer año se incluyo un implemento de discos de trabajo pesado como medio de preparación de la cama de siembra. La cadena, la cadena de discos y el disco + cadeneo + cadeneo funcionaron sin dificultad en los sitios con residuos de arbustos. Las camas de siembra preparadas por el disco + cadeneo + cadeneo incrementaron significativamente $(P<0.05)$ la densidad de plantas, en $\mathbf{1 0 0 \%}$ en el sitio franco arcilloso y en $42 \%$ en el sitio franco arenoso, en comparación con la cama de siembra obtenida con el cadeneo. Sin embargo, en el año cuando la precipitación fue $43 \%$ debajo de lo normal, en el sitio franco-arcilloso el disco + cadeneo + cadeneo incremento la densidad de plantas en $218 \%$ comparado con el cadeneo solo. En el sitio franco arcilloso las densidades de plantas en la cama de siembra de disco + cadeneo fueron menores que las obtenidas en el tratamiento disco + cadeneo + cadeneo. En el sitio franco arenoso las densidades en las camas de siembra disco + cadeneo fueron significativamente menores $(P<0.05)$ que las densidades de las camas de siembra disco + cadeneo + cadeneo,. Las densidades de siembra seguidas por el disco-cadeneo fueron significativamente mayores $(\mathbf{P}<\mathbf{0 . 0 5})$ que las densidades seguidas por el cadeneo, esto fue similar en ambos tipos de suelo. No hubo diferencias en la densidad de plantas entre las camas se siembra de disco y disco + cadeneo + cadeneo, consecuentemente, habría poca necesidad de rastrillar para limpiar los residuos de arbustos, por lo que un disco puede ser utilizado. La densidad de siembra de $2 \mathrm{~kg} / \mathrm{ha}$, comparada con la densidad de $1 \mathrm{~kg} / \mathrm{ha}$, incremento significativamente $(P<0.05)$ la densidad de plantas en $75 \%$ en el sitio franco arcilloso y en $98 \%$ en el franco arenoso. Los resultados obtenidos en este estudio indican el valor de usar el implemento disco + cadena + cadena y la densidad de siembra alta para aumentar el establecimiento del zacate sembrado, especialmente cuando la precipitación es escasa o no ocurre a tiempo. 
Conversion of brush-infested rangeland to a grassland has been shown to increase forage and livestock production (Fisher et al.1959). When the conversion is sculptured into a brush-infested landscape, it can enhance the wildlife habitat, livestock production, watershed management, and recreational enterprises (Rollins 1997). The high cost of removing brush, preparing a seedbed and planting limits the conversion practice. Research to develop cost-effective equipment for seedbed preparation and seeding which requires less land cleanup has been conducted by Wiedemann et al. (1979). We found that seedbeds prepared with heavy-duty, offset disks consistently resulted in better stands of seeded grasses than roller chopped or chained seedbeds on rootplowed land, but log-littered land often precluded the disk's use. Rootplowing, the severing of tree roots by a large horizontal blade pulled through the soil for brush control, leaves the soil surface rough and littered with logs. Chaining with large anchor chains pulled between 2 crawler tractors is well suited for use on log-littered land. This method was much lower in cost than disking, but it resulted in the poorest stands of seeded grass. Combining disking and chaining techniques resulted in the development of a "disk chain" (Fig. 1). The implement provides disking action at costs similar to chaining and could eliminate the need for raking in most brush-infested areas (Wiedemann and Cross 1980). Engineering studies of disk chains reported the pulling requirements of a diagonal unit requiring 2 tractors (Wiedemann and Cross 1982), the development of a triangular unit requiring only 1 tractor (Wiedemann and Cross 1985) (Fig. 2),

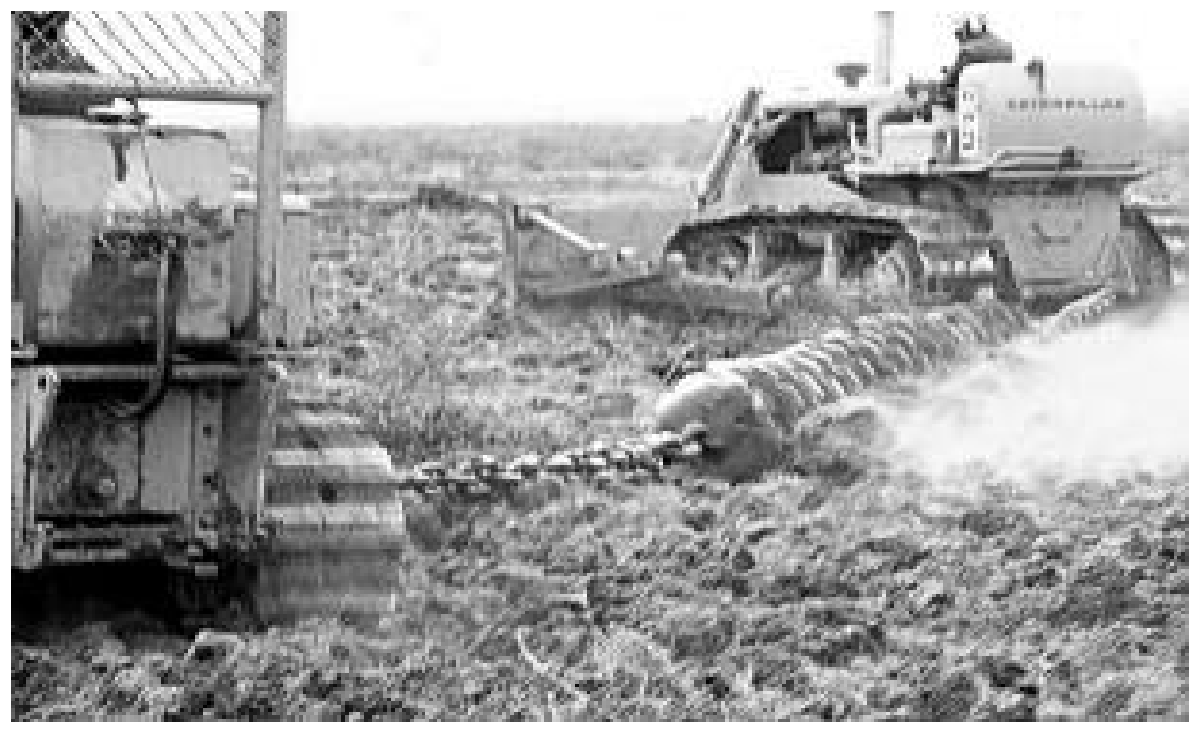

Fig. 1. Disk chain pulled between 2 crawler tractors for seedbed preparation on land littered with brush debris. (Pitchfork Ranch) for the study period.

Climatological Data, NOAA, Asheville, N.C. 28801 and the influence of operating mass on pulling requirements and depth of disking (Wiedemann and Cross 1987). Based on results from these studies, a disk chain was developed that could traverse rootplowed land littered with logs or undisturbed land infested with small shrubs (Wiedemann 1990). Moreover, pulling requirements and depth of disking can be predicted for a broad range of conditions when several engineering indices of the implement and soil are known.

Information is lacking on the efficacy of the disk chain for rangeland seeding. The objective of this study was to compare disk chaining with other methods of preparing seedbeds on log-littered, rootplowed rangeland by comparing the density of established grass plants following the first growing season after seeding for each seedbed method.
Table 1. Annual and monthly rainfall near the clay loam site (Vernon) and the sandy loam site

\begin{tabular}{|c|c|c|c|c|c|c|}
\hline \multirow[t]{2}{*}{ Month } & \multicolumn{3}{|c|}{ Vernon } & \multicolumn{3}{|c|}{ Pitchfork Ranch } \\
\hline & 1979 & 1980 & 1981 & 1979 & 1980 & 1981 \\
\hline & \multicolumn{3}{|c|}{ - } & \multicolumn{3}{|c|}{ 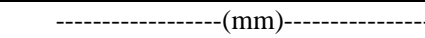 } \\
\hline Jan. & 22 & 35 & 3 & 21 & 28 & 0 \\
\hline Feb. & 7 & 11 & 15 & 0 & 10 & 30 \\
\hline Mar. & 64 & 19 & 8 & 67 & 15 & 21 \\
\hline Apr. & 36 & 75 & 72 & 36 & 14 & 68 \\
\hline May & 171 & 119 & 87 & 38 & 160 & 92 \\
\hline Jun. & 66 & 28 & 131 & 132 & 53 & 38 \\
\hline Jul. & 45 & 0 & 31 & 93 & 0 & 11 \\
\hline Aug. & 171 & 4 & 100 & 43 & 25 & 37 \\
\hline Sep. & 0 & 57 & 41 & 37 & 165 & 70 \\
\hline Oct. & 47 & 2 & 82 & 14 & 0 & 115 \\
\hline Nov. & 32 & 33 & 10 & 27 & 30 & 14 \\
\hline Dec. & 44 & 36 & 0 & 43 & 33 & 0 \\
\hline Total & 705 & 419 & 580 & 550 & 534 & 496 \\
\hline
\end{tabular}

\section{Materials and Procedures}

\section{Study Sites}

Research sites were located in the Rolling Plains vegetational resource region of northwest Texas, $40 \mathrm{~km}$ south of Vernon, Tex. $\left(33^{\circ} 57^{\prime} \mathrm{N}, 99^{\circ} 05^{\prime} \mathrm{W}\right.$, elevation $367 \mathrm{~m}$ ) and $20 \mathrm{~km}$ west of Guthrie, Tex. (33 $30^{\prime} \mathrm{N}, 100^{\circ} 30^{\prime} \mathrm{W}$, elevation 535 $\mathrm{m})$. Average annual rainfall is $652 \mathrm{~mm}$ at Vernon and $556 \mathrm{~mm}$ near Guthrie (Pitchfork Ranch). Rainfall is highly variable, and the mean distribution is bimodal, with a peak in May and another in October. Rainfall during the 3-year study is presented in Table 1 . The average frostfree growing season is more than 200 days, extending from March into November. Growing-season rainfall was tabulated for the period April through October. The long-term average is 502 $\mathrm{mm}$ at Vernon. Long-term records are not available for the Pitchfork Ranch site.

All sites have productive soils suitable for grass seeding. Soils were nearly level to gently sloping uplands (0 to $3 \%$ slope), deep, well drained, and slow to moderately permeable. Soils at the 3 Vernon sites were classified as Wichita (mixed, thermic Typic Paleustalfs) in Year-1 and Tillman (mixed, thermic Typic Paleustolls) in Year-2 and Year-3. Texture was clay loam, thus the term "clay loam site." At the 3 Guthrie sites, soils were classified as Carey (mixed, thermic Typic Argiustolls) in Year-1 and Paducah (mixed, thermic Typic Haplustalfs) in Year-2 and Year-3. Texture varied between loam to fine sandy loam, thus the term "sandy loam site." All sites were infested with regrowth mesquite (Prosopis glandulosa Torr. var. glandulosa) varying in height from 1.8 to $3.0 \mathrm{~m}$. Sites had been aerially sprayed, chained, and re-sprayed several times over the past 30 years. 


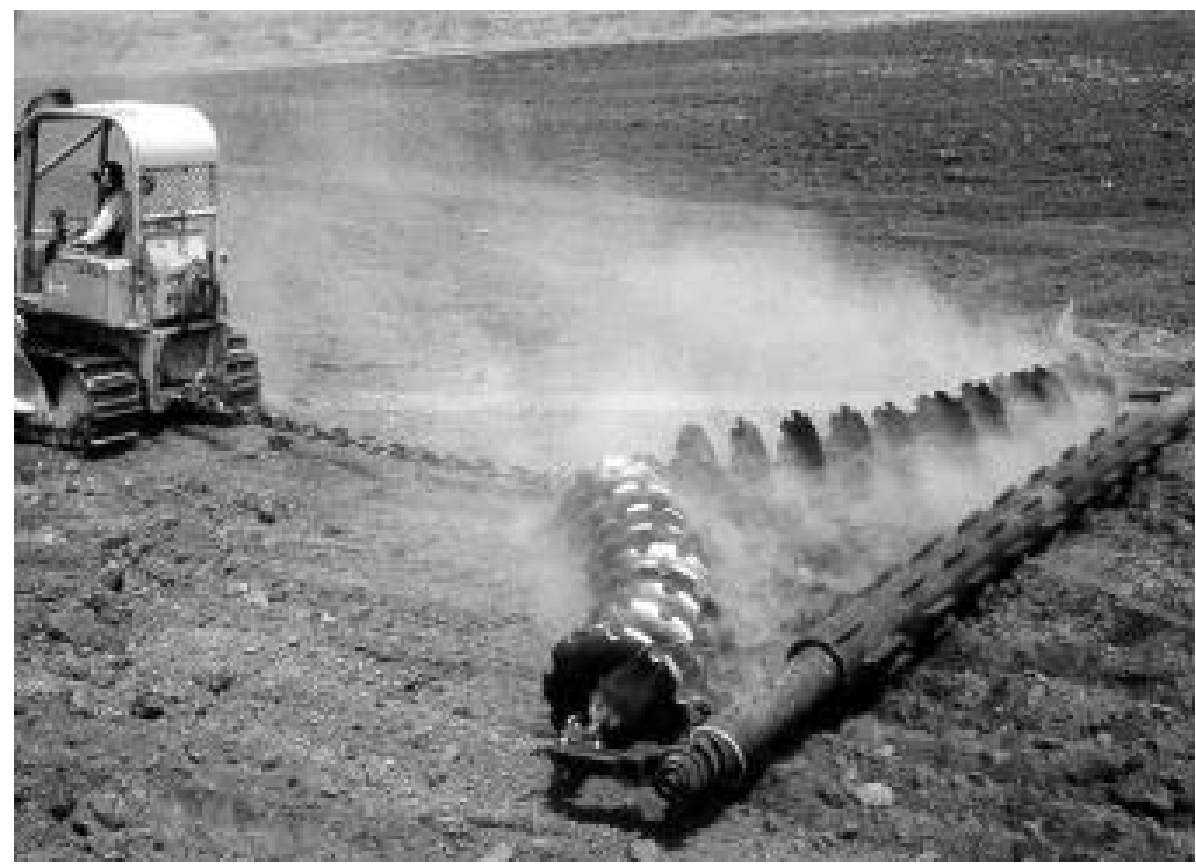

Fig. 2. Disk chain developed for single tractor pulling (Wiedemann and Cross 1985).

\section{Equipment}

Integral mounted rootplows were pulled with large crawler tractors $(175 \mathrm{~kW}$ or larger) at depths of 30 to $35 \mathrm{~cm}$ to sever mesquite roots below the bud zone. A 58mm-diameter anchor chain $(70 \mathrm{~kg} / \mathrm{m})$ pulled in a U-shape between 2 crawler tractors (104 kW or larger) accomplished the "smooth" chaining operation. The disk chain was constructed from 48-mm-diameter anchor chain with 610-mm-diameter disk blades ( $33.5 \mathrm{~kg} / \mathrm{blade})$ welded to alternate chain links. Tillage was achieved as the chain was pulled diagonally between the lead crawler tractor $(104 \mathrm{~kW})$ and the trailing crawler tractor $(48 \mathrm{~kW})$ (Fig. 1). Additional disk chain details have been described previously (Wiedemann 1990). A 2.4-m-wide, heavy-duty offset disk with 610-mm-diameter blades was used for comparisons at sites where brush debris was not a serious problem (Year-3).

An Ag-Truck aircraft (Cessna Aircraft Co., Wichita, Kans. 67277) equipped with a Thinline spreader (Transland Inc., Harbor City, Calif. 90710) was used for aerial seeding. Seeds were metered through a standard gate box in Year-1, a standard gate box plus a metering baffle in Year-2 (Wiedemann et al. 1980), and a positive metering system in Year-3 (Wiedemann 1985). Swath widths were 12 or $15 \mathrm{~m}$, and flight lines were $305-$ to $762-\mathrm{m}$ long.

\section{Treatments and Experimental Design}

Rootplowing for mesquite control was conducted in winter months. Seedbeds were prepared 1 to 14 days prior to spring seeding. Chained seedbeds were prepared by 2 passes of the smooth anchor chain pulled in opposite directions (minimal soil disturbance). Disk-chained seedbeds were prepared with a single pass of the modified anchor chain (soil disturbance similar to disking). The third seedbed preparation method, disk-chain+chain, was prepared by disk chaining followed by a single pass of the anchor chain to smooth the rough soil surface. In Year-3, a single pass of an offset disk was added as a fourth method. Treatments were installed in 1979 (Year1), 1980 (Year-2), and 1981 (Year-3), and plot size varied from $37 \times 76 \mathrm{~m}$ to $50 \mathrm{x}$ $183 \mathrm{~m}$ (width $\mathrm{x}$ length).

In Year-1, disk-chaining+chaining, diskchaining, and chaining treatments were replicated 5 times at the clay loam site. At the sandy loam site, due to an installation problem, 6 replicates of diskchaining+chaining and chaining and 3 replicates of disk chaining were established. In Year-2, 6 replicates of the 3 methods were installed at both locations. In Year-3, disk-chaining+chaining, diskchaining, chaining, and disking treatments were replicated 4 times at both locations.

Kleingrass (Panicum coloratum L.) 'Selection 75' was aerially seeded at 1 and $2 \mathrm{~kg} / \mathrm{ha}$ pure live seed at all sites. Seeding dates were 21 April 1979, 17 April 1980, and 4 April 1981 at the clay loam site and 5 March 1979, 8 May 1980, and 20 April 1981 at the sandy loam site. Each swath of the aircraft was perpendicular to all seedbed preparation methods in a block to minimize the effect of any irregularities in the seeding rate during seeding. To accommodate aerial seeding and plot size restrictions, a randomized strip-split block experimental design was used each year.

Plots were evaluated at the end of the first growing season (November). Established plant densities were determined from $100,0.1 \mathrm{~m}^{2}$ quadrat samples per plot.

\section{Statistical Analysis}

A strip-split block analysis for each soil type was calculated to determine main effects of seedbed methods, seeding rates, and years and their interactions on established plant densities (plants $/ \mathrm{m}^{2}$ ). A general linear model procedure (SAS System v6.12, SAS Institute, Inc., Cary, N.C. 27511) was used for analysis of variance with a protected Least Significant Difference method of means separation at $\mathrm{P}=0.05$. The error term for seedbeds and error term for rates rather than the wholemodel error term was used to test seedbeds and rates and their means separation. Seedbed data were also analyzed each year for each seeding rate and soil type separately. Standard errors were calculated for all means.

\section{Results}

\section{Combined Years}

Analysis of variance showed that the established plant density of kleingrass varied with seedbed preparation method, seeding rate, and year at the clay loam site, but varied only with seeding method and seeding rate at the sandy loam site $(\mathrm{P}=0.001)$. Among the main factors, seeding rate had the greatest influence on plant densities at both locations. Established plant densities on disk-chained+chained and disk-chained seedbeds were significantly greater than chained seedbed densities, but they were not significantly different from one another at the clay loam site (Table 2). At the sandy loam site, plant densities on disk-chained+chained seedbeds were significantly greater than those on disk-chained seedbeds, which were significantly greater than those on chained seedbeds.

The higher seeding rate significantly increased plant densities at both locations (Table 2). Plant densities were significantly different each year at the clay loam site. At the sandy loam site, there was no difference among years. 
Table 2. Effects of seedbed methods, seeding rates, and years on established plant densities on 2 different soils $(\overline{\mathbf{x}} \pm \mathrm{SE})$.

\begin{tabular}{lcc}
\hline \hline Treatments & Clay loam & Sandy Loam \\
\hline Seedbed preparation & - & \\
$\quad$ Disk-chain+chain & $12.1 \pm 0.9 \mathrm{a}^{1}$ & $9.2 \pm 0.7 \mathrm{a}$ \\
Disk chain & $11.6 \pm 1.0 \mathrm{a}$ & $8.0 \pm 0.7 \mathrm{~b}$ \\
$\quad$ Chain & $6.0 \pm 0.6 \mathrm{~b}$ & $6.4 \pm 0.5 \mathrm{c}$ \\
Seeding rate $(\mathrm{kg} / \mathrm{ha})$ & $12.6 \pm 0.8 \mathrm{a}$ & \\
2 & $7.2 \pm 0.4 \mathrm{~b}$ & $5.3 \pm 0.5 \mathrm{a}$ \\
1 & & \\
Years & $8.1 \pm 0.5 \mathrm{a}$ & $7.7 \pm 0.6 \mathrm{a}$ \\
1 & $10.3 \pm 1.1 \mathrm{~b}$ & $8.1 \pm 0.6 \mathrm{a}$ \\
2 & $11.5 \pm 1.0 \mathrm{c}$ & $7.8 \pm 1.8 \mathrm{a}$ \\
3 & &
\end{tabular}

${ }^{1}$ Means in columns within a treatment followed by the same letter are not significantly different $(\mathrm{P}=0.05)$.

Year $\mathrm{x}$ seedbed method, year $\mathrm{x}$ seeding rate, and method $\mathrm{x}$ rate interactions were significant at the clay loam site $(\mathrm{P}<0.004)$, while year $\mathrm{x}$ rate and method $\mathrm{x}$ rate interactions were significant at the sandy loam site $(\mathrm{P} \leq 0.05)$.

\section{Year-1}

Plant densities on seedbeds prepared by disk-chaining+chaining were significantly greater than those prepared by chaining in each of the four cases (a clay loam site, 1 \& $2 \mathrm{~kg} / \mathrm{ha}$; sandy loam site, 1 \& $2 \mathrm{~kg} / \mathrm{ha}$ ) (Table 3). Plant densities on disk-chained seedbeds were significantly greater than those on chained seedbeds in 2 of 4 cases. At the clay loam site, plant densities following disk-chaining+chaining were not significantly greater than those following disk chaining. However, at the sandy loam site, plant densities following disk-chaining+chaining were significantly greater than those following disk chaining. Average established plant densities were 8.1 plants $/ \mathrm{m}^{2}$ at the clay loam site and 7.6 plants $/ \mathrm{m}^{2}$ at the sandy loam site.

\section{Year-2}

In all 4 cases, plant densities on diskchaining+chaining seedbeds were significantly greater than densities on chained seedbeds, and densities for disk-chained seedbeds were significantly greater than those on chained seedbeds in 3 of 4 cases (Table 3). Additionally, there was no difference between densities due to disk chaining and disk-chaining+chaining. Average established plant densities were 10.2 plants $/ \mathrm{m}^{2}$ at the clay loam and 8.1 plants $/ \mathrm{m}^{2}$ at the sand loam sites.

\section{Year-3}

In all cases, there was no difference between plant densities due to disking and disk-chaining+chaining, and no difference due to disking and disk chaining in 3 of 4 cases (Table 3). Plant densities following disk-chaining+chaining were significantly greater than densities following chaining in 2 of 4 cases, and there was no difference between densities following diskchaining+chaining, disk chaining, or chaining in the other 2 cases. Average established plant densities were 11.5 plants $/ \mathrm{m}^{2}$ at the clay loam site and 7.8 plants $/ \mathrm{m}^{2}$ at the sandy loam sites.

\section{Discussion}

\section{Main Effects}

Our data indicate that diskchaining+chaining could increase plant densities as much as $100 \%$ in clay loam soil and $42 \%$ in sandy loam soil compared with chaining (Table 2). The reason the increase was less in the sandy loam soil was because chaining provided more soil disturbance (tillage) in the sandy loam soil than in the clay loam soil. Moreover, there was no significant difference in plant densities between disked and diskand seeding rates $(\bar{x} \pm S E)$. chained+chained treatments (Table 3), suggesting that there would be little value in raking so a heavy-duty offset disk could be used for seedbed preparation. The diskchain+chain, disk-chain, and chain implements traversed all debris with ease at our study sites.

The 2-kg/ha seeding rate increased plant densities over the $1-\mathrm{kg} / \mathrm{ha}$ rate by $75 \%$ at the clay loam site and by $98 \%$ at the sandy loam sites. Although the $2-\mathrm{kg} / \mathrm{ha}$ seeding rate almost doubled the plant densities over the $1-\mathrm{kg} / \mathrm{ha}$ rate, the $1-\mathrm{kg} / \mathrm{ha}$ rate achieved stand densities equal to or greater than 5 plants $/ \mathrm{m}^{2}$ which is considered successful for rangeland seeding (GPAC 1966). However, examination of the individual years indicated that the $1-\mathrm{kg} / \mathrm{ha}$ rate did not perform that well in a number of situations (see interaction discussions). If the management goal is to insure consistently sufficient stands when environmental conditions are less than favorable or to maximize stand densities, then the $2-\mathrm{kg} / \mathrm{ha}$ rate would best meet that goal.

\section{Interactions \\ Year X Seedbed Method}

In Year-2, when growing-season rainfall was $43 \%$ below normal $(285 \mathrm{~mm})$ at the clay loam site, disk-chaining+chaining improved plant densities by $218 \%$ compared with chaining (Table 4). This major difference was present at both seeding rates in the yearly analysis (Table 3 ). When rainfall was $8 \%$ above normal in Year-3 (544 mm), disk-chaining+chaining improved densities by $45 \%$ over chaining. A similar trend was present on the sandy loam site but was much less dramatic since there was only $38 \mathrm{~mm}$ difference between the high and low growing-season rainfall

Table 3. Effects of seedbed preparation methods on established grass densities within years, soils

\begin{tabular}{|c|c|c|c|c|}
\hline \multirow[t]{3}{*}{ Seedbed method } & \multicolumn{2}{|c|}{ Clay loam site } & \multicolumn{2}{|c|}{ Sandy loam site } \\
\hline & \multicolumn{4}{|c|}{ Seeding rate $(\mathrm{kg} / \mathrm{ha})$} \\
\hline & 1 & 2 & 1 & 2 \\
\hline & \multirow{2}{*}{\multicolumn{4}{|c|}{ 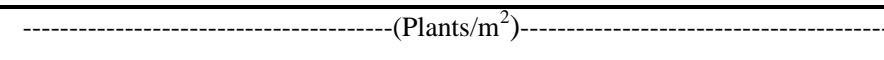 }} \\
\hline \multirow{2}{*}{\multicolumn{5}{|c|}{ 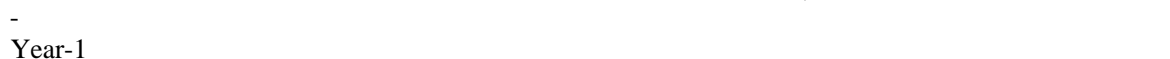 }} \\
\hline & & & & \\
\hline Disk-chain+chain & $7.5 \pm 0.5 \mathrm{a}^{1}$ & $12.1 \pm 0.4 \mathrm{a}$ & $6.1 \pm 0.4 \mathrm{a}$ & $12.9 \pm 0.6 \mathrm{a}$ \\
\hline Disk chain & $6.8 \pm 0.3 a$ & $10.5 \pm 0.5 \mathrm{a}$ & $4.7 \pm 1.1 \mathrm{~b}$ & $8.4 \pm 1.3 b$ \\
\hline Chain & $5.0 \pm 0.4 b$ & $6.4 \pm 0.8 b$ & $4.2 \pm 0.3 b$ & $8.6 \pm 0.5 b$ \\
\hline \multicolumn{5}{|l|}{ Year-2 } \\
\hline Disk-chain+chain & $9.5 \pm 1.0 \mathrm{a}$ & $17.1 \pm 2.2 \mathrm{a}$ & $6.8 \pm 0.6 \mathrm{a}$ & $12.4 \pm 1.5 \mathrm{a}$ \\
\hline Disk chain & $8.5 \pm 0.8 \mathrm{a}$ & $17.9 \pm 1.2 \mathrm{a}$ & $6.1 \pm 0.8 \mathrm{ab}$ & $11.0 \pm 1.2 \mathrm{a}$ \\
\hline Chain & $2.7 \pm 0.6 b$ & $5.8 \pm 0.9 b$ & $4.6 \pm 0.4 b$ & $7.6 \pm 0.9 b$ \\
\hline \multicolumn{5}{|l|}{ Year-3 } \\
\hline Disk & $11.1 \pm 0.3 \mathrm{a}$ & $19.4 \pm 1.0 \mathrm{a}$ & $6.1 \pm 1.1 \mathrm{a}$ & $12.1 \pm 1.3 \mathrm{a}$ \\
\hline Disk-chain+chain & $9.7 \pm 0.7 \mathrm{ab}$ & $16.6 \pm 2.0 \mathrm{a}$ & $5.6 \pm 1.2 \mathrm{a}$ & $10.8 \pm 2.0 \mathrm{a}$ \\
\hline Disk chain & $8.0 \pm 0.3 b$ & $17.2 \pm 3.3 \mathrm{a}$ & $4.7 \pm 1.4 \mathrm{ab}$ & $11.5 \pm 1.4 \mathrm{a}$ \\
\hline Chain & $7.9 \pm 1.0 \mathrm{~b}$ & $10.1 \pm 1.8 \mathrm{~b}$ & $3.7 \pm 1.0 \mathrm{~b}$ & $10.1 \pm 1.6 \mathrm{a}$ \\
\hline
\end{tabular}


totals during the 3 years. This difference in rainfall at the 2 sites is the likely reason the year $\mathrm{x}$ method interaction was significant at the clay loam site and not at the sandy loam site. These data indicate that seedbeds prepared by disk-chaining+chaining were especially beneficial when rainfall was in short supply compared with a seedbed prepared by chaining.

\section{Year X Seeding Rate}

Plant densities for the $1-\mathrm{kg} / \mathrm{h}$ a seeding rate at the clay loam site increased gradually from Year-1 to Year-3 (Table 4). In Year-1, with slightly above average rainfall, the $2-\mathrm{kg} / \mathrm{ha}$ rate increased plant densities by $50 \%$ compared with the $1-\mathrm{kg} / \mathrm{ha}$ rate; however, in Year-2, when rainfall was $43 \%$ below normal, the $2-\mathrm{kg} /$ ha rate increased densities by $97 \%$ over the 1 $\mathrm{kg} / \mathrm{ha}$ rate, resulting in a significant interaction. Thus, it appears that the seeding rate interacts with the climatic factors to give increased performance at the higher seeding rate under drought conditions. At the sandy loam site, the minimal difference in growing-season rainfall among years $(38 \mathrm{~mm})$ resulted in very little change in plant densities at the $2-\mathrm{kg} / \mathrm{ha}$ rate, a 5\% increase between Year-2 and Year-3 (Table 4). This was not the case at the $1-\mathrm{kg} / \mathrm{ha}$ rate. The plant densities at the $1-\mathrm{kg} / \mathrm{ha}$ rate increased slightly from Year1 to Year-2, and then in Year-3 the density decreased by $20 \%$. Year-3 had the highest growing-season rainfall, but much of it came in the late summer, which resulted in a decrease in plant densities at the $1-\mathrm{kg} / \mathrm{ha}$ rate. The different response between the 1and $2-\mathrm{kg} / \mathrm{ha}$ seeding rates resulted in a marginally significant interaction $(\mathrm{P}=0.042)$. These data indicate that the

Table 4. Interaction of years on seedbed methods and seeding rates $(\bar{x} \pm \mathrm{SE})$.

\begin{tabular}{|c|c|c|c|}
\hline \multirow[t]{2}{*}{ Treatments } & \multicolumn{3}{|c|}{ Years } \\
\hline & 1 & 2 & 3 \\
\hline & ------------ & $-\left(\right.$ Plants $\left./ \mathrm{m}^{2}\right)$ & -------------. \\
\hline \multicolumn{4}{|l|}{ Clay Loam Site } \\
\hline \multicolumn{4}{|l|}{ Seedbed methods } \\
\hline Chain & $5.7 \pm 0.5$ & $4.2 \pm 0.7$ & $9.0 \pm 1.0$ \\
\hline Disk chain & $8.6 \pm 0.7$ & $13.1 \pm 1.6$ & $12.6 \pm 2.3$ \\
\hline Disk-chain+chain & $9.8 \pm 0.8$ & $13.3 \pm 1.6$ & $13.1 \pm 1.6$ \\
\hline \multicolumn{4}{|l|}{ Seeding rates } \\
\hline 1 & $6.5 \pm 0.4$ & $6.9 \pm 0.9$ & $8.5 \pm 0.5$ \\
\hline 2 & $9.7 \pm 0.7$ & $13.6 \pm 1.6$ & $14.6 \pm 1.6$ \\
\hline \multicolumn{4}{|l|}{ Sandy Loam Site } \\
\hline \multicolumn{4}{|l|}{ Seedbed methods } \\
\hline Chain & $6.4 \pm 0.7$ & $6.1 \pm 0.7$ & $6.9 \pm 1.5$ \\
\hline Disk chain & $6.6 \pm 1.1$ & $8.5 \pm 1.0$ & $8.1 \pm 1.6$ \\
\hline Disk-chain+chain & $9.6 \pm 1.1$ & $9.6 \pm 1.2$ & $8.2 \pm 1.5$ \\
\hline \multicolumn{4}{|l|}{ Seeding rates } \\
\hline 1 & $5.1 \pm 0.4$ & $5.8 \pm 0.4$ & $4.6 \pm 0.7$ \\
\hline 2 & $10.2 \pm 0.7$ & $10.3 \pm 0.8$ & $10.8 \pm 0.9$ \\
\hline
\end{tabular}

higher seeding rate was beneficial in establishing higher plant densities when rainfall was in short supply or when rainfall was not timely.

\section{Seedbed Method X Seeding Rate}

At the clay loam site, diskchained+chained seedbeds increased plant densities $84 \%$ at the $1-\mathrm{kg} / \mathrm{ha}$ rate and $112 \%$ at the $2-\mathrm{kg} /$ ha rate compared to chained seedbeds at equivalent seeding rates (Table 5). There was a similar response with disk chaining. These responses were due to increased soil disturbance during seedbed preparation by disk chaining and disk-chaining+chaining over chaining. The $2-\mathrm{kg} / \mathrm{h}$ a rate resulted in more seed being placed in the microsites suitable for seed germination than did the $1-\mathrm{kg} / \mathrm{ha}$ rate. A similar response was present at the sandy loam site, but the response was not as dramatic because chaining provided more soil disturbance in sandy loam soil than clay loam soil in relationship to disk chaining and diskchaining+chaining. Thus, the interaction was significant at the clay loam site $(\mathrm{P}=0.001)$ and only marginally significant at the sandy loam site $(\mathrm{P}=0.05)$.

\section{Conclusions and Management Implications}

In the past, chaining has been the only means of traversing extensive areas of loglittered land for seedbed preparation, but successful seedings have been minimal (McKenzie 1987). Results from our 3-year study with kleingrass showed that seedbeds prepared by disk-chaining+chain-
Table 5. Interaction of seedbed methods on seeding rates $(\bar{x} \pm S E)$.

\begin{tabular}{lrr}
\hline \hline Seedbed methods & \multicolumn{2}{c}{ Rates (kg/ha) } \\
\cline { 2 - 3 } & \multicolumn{1}{c}{1} \\
\hline & $------\left(\right.$ Plants $\left./ \mathrm{m}^{2}\right)--------$ \\
Clay Loam Site & \multicolumn{2}{c}{} \\
$\quad$ Chain & $4.8 \pm 0.7$ & $7.2 \pm 0.8$ \\
$\quad$ Disk chain & $7.8 \pm 0.4$ & $15.2 \pm 1.3$ \\
$\quad$ Disk-chain+chain & $8.9 \pm 0.5$ & $15.3 \pm 1.1$ \\
Sandy Loam Site & & \\
$\quad$ Chain & $4.2 \pm 0.3$ & $8.6 \pm 0.6$ \\
$\quad$ Disk chain & $5.4 \pm 0.6$ & $10.5 \pm 0.8$ \\
$\quad$ Disk-chain+chain & $6.2 \pm 0.4$ & $12.2 \pm 0.8$ \\
\hline
\end{tabular}

ing on land littered with brush debris significantly increased established plant densities by $100 \%$ in clay loam soil and $42 \%$ in sandy loam soil compared with seedbeds prepared by chaining alone. The diskchained+chained seedbeds resulted in increased grass stand establishment over a broad range of conditions and were especially effective during years of limited rainfall. Additionally, there was no significant difference between plant densities on the disked or disk-chained+chained seedbeds. Consequently, there would be little need to rake up the brush debris so a disk could be used.

The $2-\mathrm{kg} / \mathrm{ha}$ seeding rate significantly increased plant densities by $75 \%$ in the clay loam soil and $98 \%$ in the sandy loam compared with the $1-\mathrm{kg} /$ ha rate. Plant densities were below the 5 plants $/ \mathrm{m}^{2}$ threshold on the chained seedbeds seeded at the $1-\mathrm{kg} /$ ha rate each year in the sandy loam soil and in the year when growing season rainfall was below average at the clay loam site. Plant densities on disk-chained+chained seedbeds seeded at the $1-\mathrm{kg} / \mathrm{ha}$ rate were significantly better than those on seedbeds prepared by chaining alone. In addition, diskchaining+chaining and a seeding rate of 1 $\mathrm{kg} / \mathrm{ha}$ resulted in plant densities above the threshold density of 5 plants $/ \mathrm{m}^{2}$ in both soils each of the 3 years. These data indicate the importance of using the disk-chain+chain implement, which provides more tilling action than a chain for seedbed preparation. Our data also showed that the higher seeding rate was especially beneficial in the establishment of a seeded grass when rainfall was in short supply or rainfall was not timely, or where the maximum density of grass is important.

\section{Literature Cited}

Fisher, C.E., C.H. Meadors, R. Behrens, E.D. Robison, P.T. Marion, and C.H. Morton. 1959. Control of mesquite on grazing lands. Texas Agr. Exp. Sta. B-935:11-14, 18. 
Great Plains Agricultural Council. 1966. A stand survey of grass plantings in the Great Plains, p. 51. In: J.L. Launchbaugh (ed.). Univ. Nebraska Agr. Exp. Sta. Great Plains Council Rep. No. 23.

McKenzie, D.W. 1987. Range seeding equipment, p. 260. In: G.W. Frasier and R.A. Evans (eds.). Proc. Seed and Seedbed Ecology of Rangeland Plants. USDA Agr. Res. Ser., Tucson, Ariz.

Rollins, D. 1997. Brush sculptors: an appreciation for brush, pp 1-2, In: D. Rollins, D. N Ueckert, and C. G. Brown (eds.), Proc.: Brush Sculptors Symposium. Texas A\&M Univ. Agr. Res \& Ext. Ctr., San Angelo, Tex. 76901-9714.
Wiedemann, H.T. 1985. New developments in aerial grass seeding. Paper No. AA85-004. NAAA/ASAE Joint Tech. Session at Reno, Nev. ASAE, St. Joseph, Mich. 49085.

Wiedemann, H.T. 1990. Disk-chain-diker implement selection and construction. Center Tech. Rep. No. 90-1. Texas A\&M Univ. Agr. Res. and Ext. Ctr., Vernon, Tex. 76385-1658

Wiedemann, H.T. and B.T. Cross. 1980. Equipment and techniques for seeding loglittered, rootplowed rangeland. Texas Agr. Exp. Sta. CPR-3665:100-101.

Wiedemann, H.T. and B.T. Cross. 1982 Draft of disk-chain for rangeland seedbed preparation. Trans. of the ASAE 25(1):74-76, 78
Wiedemann, H.T. and B.T. Cross. 1985. Influence of pulling configuration on draft of disk chains. Trans. of the ASAE 28(1):79-82.

Wiedemann, H.T. and B.T. Cross. 1987. Influence of operating mass on disk chain performance. Trans. of the ASAE 30(6):1637-1640.

Wiedemann, H.T., C.H. Meadors, and B.T. Cross. 1980. Hopper-gate baffle for improved aerial metering of pelleted herbicide and seed. Texas Agr. Exp. Sta. CPR3665:98-99.

Wiedemann, H.T., J.H. Brock, C.E. Fisher, and B.T. Cross. 1979. Seed metering and placement devices for rangeland seeder. Trans. of the ASAE 22(5):972-977. 